\section{The Study of Cultural Landscapes of Central Yakutia for the Development of Scientific Tourism}

\section{Viktoriya Filippova}

The Institute for Humanities Research and Indigenous Studies of the North, Russian Academy of Sciences, Siberian Branch, Petrovskogo st. 1, Yakutsk, Russia, 677027

\section{Antonina Savvinova, Yurij Danilov}

North-Eastern-Federal University, Institute of Natural Sciences, Department of Ecology and Geography, Kulakovskogo st. 48, Yakutsk, Russia, 677000

\section{Sébastien Gadal}

Aix-Marseille Univ, CNRS, ESPACE UMR 7300, Univ Nice Sophia Antipolis, Avignon Uni 13545 Aix-en-Provence, France

\section{Jūratė Kamičaitytè-Virbašiene *}

Kaunas University of Technology, Faculty of Civil Engineering and Architecture

Studentu st. 48, LT-51367 Kaunas, Lithuania

${ }^{*}$ Corresponding author: jurate.kamicaityte@ktu.lt

$\Gamma$ crossef http://dx.doi.org/10.5755/j01.sace.21.4.19501

In this article authors analyse natural and cultural landscapes for scientific tourism. Central Yakutia with the unique permafrost landscapes is a rich and large territory of sites of interest for the development of "scientific tourism" for explorers, researchers or eco-natural-tourists. There are three types of scientific tourism relevant for Central Yakutia: the aim of which is scientific research; the aim of which is practical training and education of students of educational institutions; the aim of which is introducing the history of scientific research, unique natural resources, historical and cultural heritage to a wide range of people. The objects of interest of scientific tourism - landscapes of Khangalassky region are classified according the selected types of scientific tourism using methods of secondary sources analysis and field research. The study showed that scientific tourism on the territory of Central Yakutia is quite feasible and has great prospects due to the unique landscapes. It can also give impetus for the new scientific discoveries. In one of these new areas the research is being conducted within the framework of the project RSF 15-18-20047, which justifies the application of the concept of identifying the ontological characteristics of the landscapes with the use of linguistic and mental representation of it. The determination and description of cultural landscapes, collection of field materials and mapping of the cultural and landscape zoning of Khangalassky region was funded by the RSF (Russian Science Foundation).

Keywords: Yakutia, Khangalassky region, landscapes, scientific tourism.
JSACE $4 / 21$

The Study of Cultural Landscapes of Central Yakutia for the Development of Scientific Tourism

Received $2017 / 11 / 21$

Accepted after revision $2017 / 12 / 28$

\section{ktu 1922}

Journal of Sustainable Architecture and Civil Engineering Vol. 4 / No. 21 / 2017 pp. 5-16 DOI 10.5755/j01.sace.21.4.19501 c) Kaunas University of Technology 
Recently, scientific tourism is considered to be one of the fast-pace developing types of tourism, which continues to play an increasing role in attracting tourists to the undiscovered far corners of the planet.

M.A. Vinokurov suggests that "scientific and educational tourism is a comparatively new type of international tourism which involves travelling with the aim carrying out scientific research, studying or upgrading professional skills. Paleonthological, archeological and limnological and some other types of tourism are known as special types of tourism. Additionally, participation in scientific research expeditions, conferences, symposiums is also included into the scientific tourism category." (Vinokurov, 2004, p. 22).

Scientific tourism can be subdivided into the following types (Ereshko F. I., 2006): introductory natural and anthropogenic objects and samples are shown to tourists and the qualified explanations are given; subsidiary participation - tourists take part in scientific and related activities as support personnel, for example participate in restoration work, field research, i.e. independent research of tourists in cooperation with scientific personnel.

Presently, we are witnessing a new phenomenon - congress tourism and the implementation of scientific expeditions and stations which are included into the scope of tourism. Generally, using their potential is aimed at discovering new "desolate" routes, at preserving and developing national parks, sanctuaries, reviving water resources and the fishing industry as well as flora and fauna, and, lastly, making prominent the ecological problems of tourism. One of the key factors in such a co-operation has been and still remains to be different scientific institutions and their staff members. The result of the work would be undergoing positive changes of the landscape in accordance with the goals the researcher has set; another result would be the formation of a special cultural landscape type, i.e., scientific landscape (Suleymanov, 2014).

The territory of Yakutia lies in the north-eastern part of the Russian Federation and occupies 1/5 of its total territory; it is an attractive region in terms of scientific tourism development due to its extreme climatic conditions, vast territory and a unique and diverse landscape. The initial stage of scientific tourism development in Yakutia is strongly connected with the study of the territory of Yakutia, the Arctic in the era of great geographic and scientific discoveries. Researchers from Russia and all over the world, Russian fantasy writers and romanticists made a great contribution to the scientific research of the North. They also helped to raise a romantic interest for adventures connected with survival in the extreme climatic and natural conditions. Among these events, the most significant one was the visits made by distinguished scientists and their scientific discoveries. For instance, few people know that during his trip around the world, Georg Adolf Erman visited Yakutsk in spring 1829 in order to observe the Earth's magnetic field phenomenon. Based on Erman's observations, Carl Friedrich Gauss came up with his own magnetic field theory (Obruchev, p.14).

R.I. Ivanova suggests that the most visited modern scientific tourism areas in the Sakha Republic (Yakutia) are the Lena Pillars National Natural Park, the Kisilyakh Mountains, the Diring Uryakh paleonthological camp of the prehistoric period, Byulyus glacier, The Emelyan Yaroslavsky Yakut State Museum of History and Culture of the Peoples of the North and its affiliated branches, The Druzhba Museum and Sanctuary of History and Architecture, the Orto Doidyu Zoo, the Mammoth Museum, the P.I. Melnikov Permafrost Institute of the Siberian Division of the Russian Academy of Science, the Ytyk Khaya ethnographic complex, the Mir pipe, a diamond-mining carrier, etc (Ivanova, 2012).

Other interesting objects can be added to the list, namely:

- The Batagaika faulting in the Verkhoyansky region, which is a unique frost-thaw basin formed as a result of thawing processes; the basin is a kilometer wide and approximately 100 meters deep in some parts. Scientists have already proclaimed Batagaika one of the main objects in Russian and the world suitable for permafrost studies. Apart from researchers, tourists have also shown interest in the visiting the basin. Soon it may acquire a status of a popular touristic zone. 
The Mammoth Mountain, a unique location of the Middle Miocene period complex of natural fossils and Middle Pleistocene period mammal fossils, which is situated on the border of the Tatinsky and the Tomponsky regions. This area resembles a plateau, about 80 meters in height and it is one of the routes of international geological expeditions. In August 2008, under the leadership of A.V. Brushkov, a professor of geological and mineral sciences at MSU (Moscow State University), Russian and international scientists found live microorganisms, the age of which is approximately 15 million years. These microorganisms were discovered in the sand layers of the Mammoth Mountain and they were previously undiscovered by other scientists. Experiments and laboratory studies revealed sensational results - scientists have discovered bacilli which are able to prolong life duration (Mamontova gora - http://rulandinfo.ru/tours/214/763/?sphrase_id=3791).

- The Pleistocene Park is the main project of the North-Eastern Scientific Station. The park is located beyond the Polar Circle in the Chersky Township of the Sakha Republic (Yakutia). The idea of creating a Pleistocene park founded by a Russian researcher S.A. Zimov was to introduce the preserved species of large fauna with the aim of restoring the soil and landscape typical for the mammoth tundra steppes, which would make it possible to restore a highly productive grass layer and ecosystem that became extinct 10 thousand years ago with the end of the Ice Age together with the end of the Pleistocene period. Zimov's studies on permafrost, greenhouse gas emissions and mammoths attract the attention of many scientists worldwide.

- Oymyakon, or the Pole of Cold is an area which annually attracts scientists who are interested in the special living conditions of the local population in an extreme climate. In addition, there is a lake Labynkyr located on the territory of the region, where according to one legends lives a giant animal, more commonly known as the Labynkyr Devil. In the 60's and 70's, several expeditions were held and several touristic groups have visited the Labynkyr area; scientific expeditions on finding undiscovered gigantic animals are still held today and attract tourists as well as researchers.

Thus, it can be clearly seen that Yakutia has a significant potential for the development of scientific tourism.

The aim of the study is to classify the landscapes of central Yakutia (namely Khangalassky region) as the objects of scientific tourism and to specify their elements and features important to scientific tourism.

\section{Classification of landscapes and scientific tourism}

Being potentially highly attractive areas for scientific tourism, natural and cultural landscapes Methods of Yakutia are characterized as having unique physical and geographical (permafrost) processes. The only existing specialized Institute of Permafrost of the Siberian Division of the Russian Academy of Sciences located in Yakutsk makes a significant contribution to the study of centuries-old permafrost layers and unique permafrost landscapes (alases, baidzherakhs, bulgunnyakhos, and yedomas). The Institute cooperates with many countries worldwide (China, Mongolia, South-Korea, Germany, Canada, USA, Japan and France). The Institute researchers also take part in international arctic programs, which raise interest among many scientific researchers globally; these programs also promote the development of scientific tourism in Yakutia. The Institute staff holds research on the study of the process of the permafrost zone evolution under the influence of natural and anthropogenic factors; they also evaluate the temperature and mechanic impact of engineering constructions on the permafrost ground layers; another aspect of the research is to hold fundamental and applied research studies in the area of geological cryology (permafrost studies) including landscape classification. 
Presently, the problem of landscape classification remains to be solved due to its high complexity. Scientists continue holding research in this area (Mamay, 2005). In our opinion, among the classifications of natural and territorial complexes, the most empirically and practically valuable are classifications provided by N.A. Solntsev (2001), F.N. Milkov (1966), A.G. Isachenko (1991), et al. They managed to solve one of the main problems - to identify the main units for a classification. Such notions as section, class, type, and landscape format became widely-recognized (Martsinkevich, 2005). The choice of a classification was in favor of a method suggested by F.N. Milkov as a basic one for the studies of Yakutian landscape. This classification has a number of advantages: the non-dependency of the taxonomic data in general and of each taxonomic unit in particular, namely - geological and geomorphological as well as biohydroclimatic. This creates a universal classification system for contrasting areas. Another advantage of this classification is its correspondence to main approaches in singling out natural and territorial complexes with different permafrost features (DPF) (Fedorov, 1991). Milkov's idea on the organization and principles of landscape differentiation are presented in his taxonomic system which takes into account three main areas of natural environment differentiation: regional complexes, typological complexes and paragenetic complexes.

Regional complexes are genetically unified, territorially complete and unique landscape complexes. Typological complexes are morphologically unified, genetically diverse landscape complexes with a discontinuous range. Paragenetic complexes include systems of adjacent and genetically connected regional and typological complexes. Each range represents an independent selection of units, each used for specific goals: regional complexes are used for zoning; the typological complexes are used for mapping; the paragenetic complexes are used for carrying out a systematic landscape analysis. Based on the aspects mentioned above, A.N. Fedorov suggested adding one more criterion in the basis of typological zoning that would take into account the permafrost zone layers. This criterion nowadays forms the basis of landscape zoning in Yakutia. The principles in the basis of this taxonomic system allow solving the problems of a "horizontal" classification of permafrost landscapes and their mapping more rationally. This system was rearranged in order to hold research in the sphere of permafrost layers development and to evaluate the sustainability level of the permafrost landscapes (Landshaftyi Yakutii, 2016). The problems of studying the sustainability of permafrost landscapes of Yakutia and the population's adaptation to the landscape and climate changes are the main focus for scientific researchers, tourists and photographers, who are interested in scientific research results in one of the regions of the Russian Federation with unique and extreme natural and climatic conditions.

Cultural landscape is an entire complex of ethnic groups' lifestyle characteristics in specific natural and geographic conditions. The surrounding geographical environment, the time of settlement and territorial development, various fishing and hunting techniques as well as national traditions of the peoples that populated these lands - all these aspects caused a considerable impact on the formation of the cultural landscape. Presently, there are very few landscapes remaining which had not experienced a direct or indirect impact of the human activity. In their turn, landscapes, which inevitably were involved in the human activity, play a significant role in forming the consciousness, an aspect which finds its reflection in culture and different social and economic processes.

In modern cultural geography, the topic of special organization of cultural landscapes causes many discussions, which is connected with differences in understanding the notion of cultural landscape itself and the various approaches to the study of cultural landscape suggested by Russian scholars, namely: Y.A. Vedenin, V.L. Kagansky, B.B. Rodoman, V.N. Kalutskov, T.M. Krasovskaya, M.V. Ragulina, R.F. Turovsky, M.E. Kuleshova, G.A. Isachenko, V.A. Nikolayev, E.Y. Kolbovsky, V.A. Nizovtsev et al. The methodological aspects of studying ethnocultural landscapes are described in the fundamental research carried out by V.N. Kalutskov, Y.A. Vedenin, T.M. Krasovskaya, M.V. Ragulina, Y.G. Simonov et al. (Kalutskov, 2011; Vedenin, 2004; Krasovskaya, 2003; Ragulina, 2015; Simonov, 1998). 
Meanwhile, ethnocultural landscapes in Russia are not widely-studied, especially in the polyethnic northern territories. In the study of Yakutia's cultural landscape, the Republic serving as a bright example of polyethnic territory, researchers mainly focus their attention on the ethnocultural approach due to a great variety of special natural, ethnological, cultural and economic features of Yakutian territory. Specific aspects of ethnocultural landscape include: ethnic composition, dermic diffusion, culture, history of Yakutia's territorial development, and economic development. These aspects were described by ethnologists, historians, area researchers, and geographers in their fundamental works, to name a few - S.A. Tokaryev, V.L. Seroshevsky, R.K. Maak, G.P. Basharin, B.O. Dolgikh, I.S. Gurvich, A.P. Okladnikov, V.A. Tugolukov, V.N. Ivanov, A.S. Parnikova, V.B. Ignatyeva, E.N. Fyodorova. One of the latest works devoted to the complex study of ethnocultural landscapes of Yakutia was written by Z.F. Degteva (Degteva, 2017).

The study of Yakutia's cultural landscape using an interdisciplinary approach was first suggested by the staff members of the Institute for Humanities Research and Problems of the Indigenous People of the North. They singled out the differences and similarities in the formation and functioning of the rural cultural landscape, which developed in the last 30 years of the last century and was existing in the first few decades of the $21^{\text {st }}$ century. They accomplished this using local examples of Yakutian villages of the central and Viluy regions of Yakutia (Vinokurova, 2014).

Both natural and cultural landscapes of Yakutia are interesting objects for the development of tourism in general and scientific tourism in particular. However, unfortunately, it must be stated that there are no existing touristic infrastructures for attracting tourists closely located to the unique landscapes in the hidden corners of Yakutia.

Summing up we have decided to classify natural and cultural landscapes of Khangalassky region in central Yakutia and clear out their elements and components as objects of interest of scientific tourism performing analysis of secondary sources and field research.

\section{The landscapes of Khangalassky region for scientific tourism Landscape resources}

An example of the most convenient area from the point of view of providing the tourist infrastructure and the availability of tourist resources necessary for the development of scientific tourism is the territory of the Khangalassky region, which has unique resources for the development of scientific tourism: a variety of natural landscapes, the presence of ethnographically interesting regions, interesting historical complexes, architectural monuments, archaeological sites, centres of various national folk crafts, as well as a developed system of scientific research in broad areas (Fig. 1).

Before, to classify natural and cultural landscapes and their elements and components in order to develop scientific tourism in the Khangalassky region, we will consider separately the existing classifications of natural landscapes, as well as the cultural elements and components of the landscapes of the area.

The territory of the Khangalassky region can serve as an example of a convenient touristic area in terms of touristic infrastructure and resources that it contains, which are necessary for the development of scientific tourism as both - a large-scale activity and as an exclusive type of activity.

The territory of the Khangalassky region has a great natural potential for the development of scientific tourism. One of the main natural resources of the region is the Lena Pillars Natural Park, which was included into the UNESCO List of World Heritage in 2012. The administration of the park takes an active part in creating and promoting touristic products on the territory of the park; it also closely cooperates with scientific institutions to hold scientific paleontological, limnological, and geocryolithic research. Since the time of its establishment, there have been scientific studies held by Russian and international scientists, students and natural conservation organizations. 


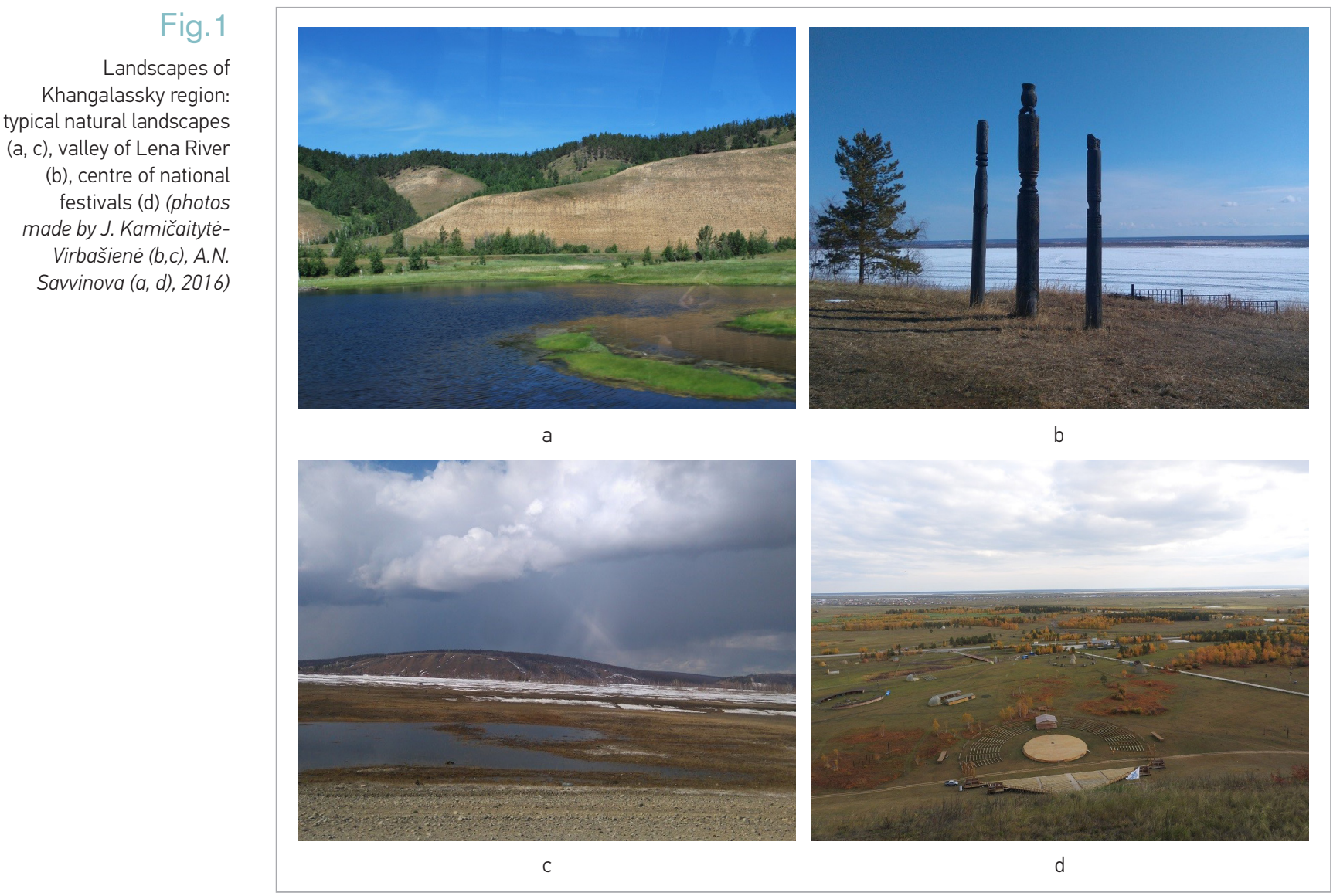

\section{Landscape geographic and geologic structure}

The Khangalassky region is located in the central part of Yakutia and it borders with three landscape provinces: the Lena-Amginsky Alasnaya plain landscape, the Lena-Amginsky sand landscape, and Lena-Aldansky karst landscape (Fedorov, 1991). This fact defines the relatively wide range of conditions for the functioning and development of various typological natural and territorial complexes (NTC) in terms of their genesis and structure.

Upland area types differ from other types by the discontinuity of the lithogenic basis and it is subdivided into tow subtypes. The karst subtype of the upland area is represented by fruticulosey as well as combinations of fruticulosey and mossy larch areas, with mixtures of spruce trees which are mainly present in the eluvium of the Cambrian soil. The sandy upland subtype is mostly spread on the eluvium of the Jurassic period with a lichen and fruticulosey as well as fruticulosey and pine tree forests. Bottomland type of landscape with alluvium sediment is occupied by the valley forests, dwarf birches and willow shrubs. Slope type of landscape on carbonate formations of the Cambrian period is mainly represented by the larch, fruticulose and alder forest areas. These forests located on the slopes of warm expositions are gradually replaced by steppe-like plains and fruticulose-like pine trees. Territories with areas of increasing external agencies and the revelation of Cambrian formations are presented by flora growing on rocky areas (Plan..., 2014).

The inter-plain type of areas with sabulous clay-loam formations are covered with fruticulose and pleurocarpous moss larch forests and it can be seen in the eastern area of the park. Sand bed type of landscape is presented in the medium-altitude sand terraces of the Lena River on the Khangalassky territory of the natural park with fruticulose and lichen-fruticulose and fruticulose-lichen 
pine trees. Within the area of the low-altitude terrace type of landscape on the aluvium sedements there are valley forests, willows and plains. Apart from studying the landscape, the Permafrost Institute in cooperation with the Oxford University (Great Britain) studied the permafrost layer condition by dating the shelf-stones in the karst caves in 2013.

The natural objects which are of interest to scientific tourism in Khangalassky region are paleontological, geological, limnological, geocryologic objects.

An example of paleontological objects is the Lena Pillars on the UNESCO World Heritage List, located on the right bank of the river Lena, with a length of $40 \mathrm{~km}$, which represents the numerous remains of the destruction of bedrocks of Lower Cambrian limestone with an age of 530 million years, where unique fossils are found.

Locations of remains of fossil organisms that have not undergone any significant changes, where whole fragments of extinct animals are preserved in the fossil state, are of great importance for the world science, in particular for studying the Cambrian evolutionary explosion.

Now in the world paleontological tourism when people visit places of finds and scientific institutions which are engaged in their studying gains popularity. Scientific works aimed at revealing the paleontological potential of the Lena Pillars natural park will help to establish the Republic as the paleontological center of Russia for studying the Cambrian period.

Geological monuments are scientifically valuable objects or landscapes on which it is possible to conduct research of objects revealing tectonic features of the region and geomorphological observations. These include the Buotama rocks, which are located below the mouth of the river. Hariya-Uryakh. The Buotama River flows in the vicinity of picturesque cliffs, not inferior in beauty to the famous Lena Pillars. Particularly impressive are the colourful outcrops of marls, limestones, dolomites dating back to the Cambrian period (400-500 million years ago). In the same group can be attributed Sinsky poles, not as high as Lensky ones. They rise above the river a little more than 100 meters. However, they leave no less impression of their grandiosity, especially where the vertical wall goes directly under the rapid flow of the river.

Limnological studies for the inclusion of lakes in the list of scientific tourism sites are conducted on many lakes of the Khangalassky region. However, the most interesting from the point of view of scientific study is Lake Borulaakh, located on the watershed of the river Lena and the river Buotama. Its uniqueness lies in the fact that in winter, usually in December, the water level drops sharply by 8-10 meters. Thus, the lake is almost completely shallow. The conducted studies confirmed the presence of active karst processes under the bottom of Lake Borulaakh and in the adjacent territory, as evidenced by the descent of water with the collapse of the lake ice cover and the funnel-shaped depressions of the lake bottom. Dynamics of the water mode of the karst lake Borulaakh is the proof that permafrost karst - a unique natural phenomenon, and the lake is only a part of the large-scale karst system developing in carbonate breeds of the Cambrian in the territory of the Natural park "Lena Pillars".

In 2015 and 2016, an expedition team of the Yakut division of the Russian Geographic Society in the Sakha Republic (Yakutia) held a scientific trip to the Borulakh Lake located on the territory of the Natural Park in order to study the unique whistling karst lake, in which the water runs out into the soil through funnels during the winter period and recommended its inclusion in the routes of scientific tours.

To the unique geocryological objects of the region can be attributed Tukulans (from Evenki "tukala" - sand, "tukalan" - sandy massif or dune). These are typical sand formations of cryolithozone with unique vegetation, which are large active dynamic waved sand massifs, the development of which is associated with geographic medium. Most researchers believe that the Tukulans are a remnant of an unusual, peculiar desert that once occupied huge areas, as adjacent to modern 
Tukulans, there are vast fields of smoothed dunes already completely covered with taiga. The three stages of the Tukulans history are known: accumulation of sands as a result of their deposition by rivers, transfer and redeposition by the wind, fixation of sandy massifs by vegetation. Dune complex are widely distributed in the basins of the Vilyuy and the Lena rivers and were described by the researches in the 19th century. On the territory of the Khangalassky region there are two tukulans. "Kysyl Elesin", located 8 kilometres from the mouth of the Buotama river - a dune formed from the sand blown by prevailing winds from the slope of the terrace. Tukulan "Saamis Kumaga" (length - about 5 kilometres; the widest part - about 850-900 meters) consists of ridges and hollows shafts-blowing, having a depth of 20 meters. In some basins there is rather lush vegetation - pine trees at the age of 30-35 years, with a height of 12-14 meters, thickets of rosehip and grass. The combination of geological and geomorphological data, in particular the study of fossil pollen and spores, as well as discoveries of mammoths, bison, and other extinct mammals, indicate that the dune complex is a relic of the so-called cold deserts. That is why these unique natural objects are of interest for scientific tourism.

All of the natural objects mentioned above are located on the territory of natural Park "Lena pillars" and are represented as the unique object for research.

Annually, teams of employees from the Institute of Biological Problems of the Cryolithozone of the Siberian Division of the Russian Academy of Sciences hold research on the territory of the park. Academic staff members and students of the North-Eastern Federal University (NEFU) also hold research there (Lenskie stolbyi - http://lenapillars.ru/posts/view.aspx?id=150).

Researchers from the Permafrost Institute of the Siberian Division of the Russian Academy of Sciences also hold scientific research of the permafrost layers and landscapes in the Lena Pillars Natural Park. The landscape study approach allows to establish objectively and complexly the special features of the geological, geomorphological, botanic and other natural monuments using the data of historical development, the place and role in the modern natural environment, and the evolution of the natural objects on this territory.

Geographical features and natural resources create a unique background for the cultural and architectural objects, events that carry historical significance, and are the attraction for tourists. Historical and cultural potential is an important competitive advantage of the Khangalassky region and is based on a heritage that includes a social cultural environment with established canons and traditions, features of activities both economic and household. There are many objects of cultural heritage in the territory of this region; their uniqueness is defined by a prevalence of archaeological and ethnic and cultural objects which perform a very important social function: archaeological materials are used in the region's local museum expositions. Traditional festivals are held annually. The historical heritage of the post stations of the Irkutsk-Yakutsk post route is well-preserved and is used in forming the touristic products (Kontseptsiya..., 2014).

\section{The anthropogenic objects: tangible and intangible cultural heritage}

The historical and cultural resources include architectural monuments, archaeological excavation sites, museum complexes, monumental architecture objects, etc. Taking this into consideration, we singled out the following groups of such resources analysing the cultural landscapes of the Khangalassky region:

1 Historical monuments which include archaeological monuments (ancient nomad campsites). The objects are represented by Diring Uryakh, an ancient nomad campsite; petroglyphs and runic signs near the Bulgunyakhtakh village on the Elansky Pillars territory; Kullaty area, where the Tygyn Darkhan (a powerful ancestor of the Khangalassky region Yakuts) family residence was located; Tit Ebye area, the place where Munyan Darkhan died and where Tygyn Darkhan was born; the Edey village (which can reveal interesting areas and legends connected with Tygyn Darkhan); 
2

Civil and cultural architecture monuments include a list of civil and cultural architecture objects, which is compiled by the Ministry of Culture and Spiritual Development of the Sakha Republic (Yakutia) and is officially called "The Objects of Cultural Heritage and Religious Value". This group includes separate buildings and building ensembles which belong to the category of civil and cultural architecture and monumental art, objects of monumental architecture (memorials, sculpture objects, etc.). Such examples include: the Samartai open-air architectural museum complex (historical and cultural monuments: Kachikatskaya Nikolayevskaya Church (1892), grain dryer, hexagon-shaped house - babaryna (18th century), the rich landowner Kirill's shed (19th century), a traditional summer dwelling - balagan (18th century));

3 Social and cultural objects are objects of a cultural or education value; they are objects of 3 cultural heritage. This group includes works of art, traditional forms of art, the entire scope of the traditional or national culture, the language, cuisine, traditions and customs. Social and cultural objects include museums, expositions, art galleries, theatres, concert halls, cultural halls (Information..., 2017). The main objects, listed in this group are represented by the following examples: an archive library of Mikhail Nikolaev, the first president of the Sakha Republic (Yakutia); a ceremonial complex for holding the national Ysyakh Erkeni holiday on the territory of the Orto Doidyu touristic complex; municipal cultural institution - the G.V. Ksenofontov Khangalassky Region Local Lore Museum; the Naum Zasimov Khangalaskaya Art Gallery; A Postman's Courtyard, a postman's household museum (museum, outdoor buildings, shed, a horse stable, a smithery, etc.).

\section{Proposal of landscape typology for scientific tourism}

On the basis of the analysis of spatial differentiation of natural landscape and historical and cultural objects of the Khangalassky region, cultural landscape areas with proposed types of scientific tourism are identified. As a result of cultural and landscape zoning within the boundaries of the study area, five regions were identified that have the following characteristics (Fig. 2):

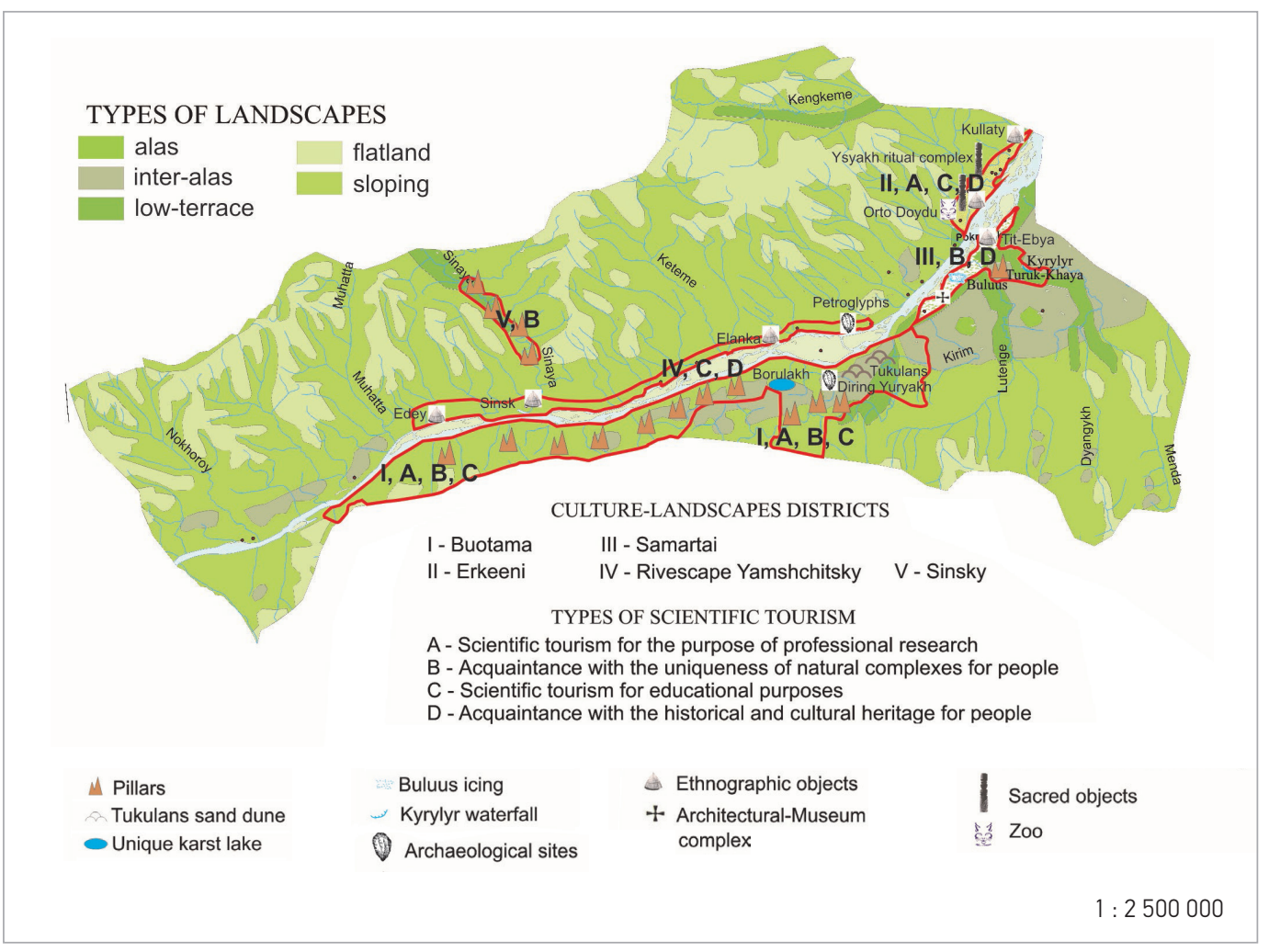

\section{Fig. 2}

Cultural and landscape zoning of Khangalassky region (made by V.V. Filippova, A.N. Savvinova, 2017) 
I. Buotama cultural and landscape area is located within the boundaries of the national nature park "Lenskie Stolby". The landscapes of this region are represented by the slope type of terrain on which the Lena and Buotama pillars and rocks are located. In the area of sloping terrain and Prisklonovoe areas of the upland type there is located sandy desert - dune complex Samys Kumaga, Kysyl Elesin. The greater part of this territory is not suitable for the population, but the small-valley type of terrain is suitable for housing, as evidenced by the ancient settlement Deering-Yuryakh. In view of the limited visits to the territory of the natural park in this cultural and landscape area, it is possible to conduct scientific tourism for the purpose of professional research and educational purposes. The presence of such objects as Deering-Yuryakh and Lake Borulah allows to conduct excursions for acquaintance with the uniqueness of natural complexes for a wide range of people.

II. The cultural and landscape district "Erkeeni" is located on the same valley of the river Lena, between Tabaginskiy cape in the north and the city of Pokrovsk in the south. The presence of low-terraced and small-valley types of terrain served to the fact that this valley is one of the three anciently inhabited valleys in central Yakutia. This cultural and landscape area in ancient times was inhabited by the Yakut hangalassian clans and this valley is considered the residence of the progenitor of the Yakuts Omogoy Bai. There is an archaeological monument of Kullata dating back to the early Bronze Age or the late Neolithic. This region is currently populated by the Yakut population, and the majority of the population of the Khangalassky district lives in this valley. At present, the tourist complex "Orto-Dojdu" is being formed here, which combines a ritual complex for the national holiday "Ysyakh Erkeeni", a zoo, a shooting club, a sports and entertainment complex "Tekhtur". The presence of many natural, sacral and historical, and cultural sites allows us to conduct professional research here, organize tourism for educational purposes, organize excursions for acquaintance with the historical and cultural heritage of the Sakha people. Visiting the northernmost zoo will allow you to familiarize yourself with the uniqueness of natural complexes of the area.

III. The cultural and landscape area "Samartai" is located partly on the same valley of the right bank of the river Lena and in the interfluve of the Luteng-Menda rivers. This area is the only populated area on the right bank of Lena River. All settlements are located on the high terraces type of terrain (modern valley of large rivers). The presence in the territory of this cultural landscape of historical and architectural monuments from the 18th-19th centuries allowed the creation of the ethnographic museum "Samartai" in 1991, allowing to conduct historical and cultural and agrarian-historical excursions. Due to the presence of valley-accumulative (ice-covered) mid-taiga with continuous permafrost rocks, there are such unique objects as ice Buluus and waterfall Kuruluur where tourists can get acquainted with the uniqueness of natural complexes.

IV. The riverscape Yamshchitsky cultural and landscape area extends along the left bank of Lena River from the village Eden to the village Bulgunnaytakh and occupies the territory on which the main postal route from Irkutsk to Yakutsk passed previously. The settlements of this region were laid down mainly as Yamschitsky postal stations. Unlike in other cultural and landscape areas, the descendants of the Cossacks and coachmen, who were engaged in protection and transport, lived in this area. Their economic activity and impact on the surrounding landscape were very specific. The presence of historical and cultural monuments of the Russian population allows us to conduct historical, cultural, agrarian-historical and ethnographic excursions here.

V. Sinsky cultural and landscape area is located in the valley of the river Blue and unlike the other above-mentioned cultural and landscape areas is uninhabited. The slope type of terrain and the denudation-remnant middle taiga of continuous perennial-frozen rocks contributed to the formation of the Sinsky pillars, which are a natural monument of the Republic of Sakha (Yakutia). The Sinsky pillars are not inferior in their beauty to the famous Lena Pillars and can attract tourists interested in unique natural complexes.

The conducted research shows that the main specialized types of scientific tourism that can be developed in the territory of Khangalassky region are the following: tourism for the purpose of scientific research, tourism for educational purposes, tourism for the acquaintance with the unique- 
ness of natural complexes, and tourism for the acquaintance with historical and cultural heritage for a wide range of people.

Natural landscapes and the objects of historical and cultural heritage of the Khangalassky region are the basis for the development of scientific tourism. However, we have to state that these areas lack the necessary infrastructure, which is one of the main factors for the socio-economically and ecologically effective development of scientific tourism. Recognition of these objects as potential areas of scientific tourism and the creation of the necessary infrastructure will help to form the foundations for a new and promising tourist destination and increase the tourist flow in the region. In general, the selected cultural and landscape areas reflect the spatial natural, ethno-cultural and historical-cultural features of certain parts of the Khangalassky district and are not final. Further, in the process of this zoning, it is possible to include the socio-economic and economic factors of the Khangalassky district. This aspect will enable the use of cultural and landscape zoning for the purposes spatial planning.

\section{Conclusions}

Degteva Zh.F. Prostranstvennaya organizatsiya etnokulturnyih landshaftov Yakutii. [Spatial organization of ethno-cultural landscapes of Yakutia]. Dissertatsiya na soiskanie uchYonoy stepeni kandidata geograficheskih nauk: Spetsialnost 25.00.24 - Ekonomicheskaya, sotsialnaya, politicheskaya i rekreatsionnaya geografiya. Smolensk, 2017.

Ereshko F.l. Nauchnyiy turizm - tsel i sredstvo progressa $v$ razvitii regionov [Scientific tourism - the purpose and means of progress in development of the regions] // http://archiv.council.gov.ru/files/journalsf/item/20061107123724.pdf

Fedorov, A.N. Merzlotnyie landshaftyi Yakutii: metodika vyideleniya i voprosyi kartografirovaniya [Permafrost landscapes of Yakutia: methods and mapping]. / A.N. Fedorov. - Yakutsk: Institut merzlotovedeniya SO AN SSSR, 1991. - $140 \mathrm{~s}$

Isachenko, A.G. Landshaftovedenie i fiziko-geograficheskoe rayonirovanie [Landscape science and physical-geographical zoning]. / A.G. Isachenko. - M.: «Vyisshaya shkola», $1991-366 \mathrm{~s}$.

Ivanova R.N. Soderzhanie i ob'ektyi nauchnogo turizma $v$ Yakutii [The contents and objects of scientific tourism in Yakutia] // Vestnik Severo-Vostochnogo federalnogo universiteta im. M.K. Ammosova. 2012. Tom. 9. \#2. S. 73-77.

Kalutskov V.N. Etnokulturnoe landshaftovedenie. M.: Geograficheskiy fakultet MGU, 2011. - 112 s.

Kulturnyiy landshaft: Teoreticheskie i regionalnyie issledovaniya. Tretiy yubileynyiy vyipusk trudov seminara «Kulturnyiy landshaft» // Otv. red. V. N. Kalutskov, T. M. Krasovskaya. — M.: Izd-vo Mosk. un-ta, 2003.

Kulturnyiy landshaft kak ob'ekt naslediya / Pod red. Yu. A. Vedenina, M. E. Kuleshovoy. - M.: Institut Naslediya; SPb.: Dmitriy Bulanin, 2004. - 620 s.

Kontseptsiya razvitiya turizma v MR «Hangalasskiy ulus» Respubliki Saha (Yakutiya) do 2025 g. TThe concept of tourism development in Khangalassky ulus of the Sakha Republic (Yakutia) up to 2025]- Yakutsk, 2014. Landshaftyi Yakutii: monografiya [Landscapes of Yakutia] / [Yu.G. Danilov i dr.]; otv.red. Yu.G. Danilov. - Yakutsk: Izdatelskiy dom SVFU, 2016. 86 s.

Lenskie stolbyi [Lena Pillars] - http://lenapillars.ru/ posts/view.aspx?id=150

Mamay, I.I. Dinamika i funktsionirovanie landshaftov [Dynamics and functioning of landscapes] / I.I. Mamay. - M.: Izd-vo Mosk. un-ta, 2005. - 138 s.

Mamontova gora [Mamontova mountain] - http://rulandinfo.ru/tours/214/763/?sphrase_id=3791

Martsinkevich, G.I. Landshaftovedenie [Landscape science] / G.I. Martsinkevich. - Mn.: BGU, 2005. - 200 s.: il. Milkov, F.N. Landshaftnaya geografiya i voprosyi praktiki. [Landscape's geography and practice issues] / F.N. Milkov. - M.: Myisl, 1966. - $156 \mathrm{~s}$.

Obruchev V.A. Istoriya geologicheskogo issledovaniya Sibiri [History of geological exploration of Siberia]. - L.: Izd-vo AN SSSR, 1933. - 230 s.

Plan upravleniya Prirodnogo parka Lenskie Stolbyi na 2014 [The management plan of the Nature Park "Lena Pillars"] - https://minpriroda.sakha.gov.ru/uploads/ ckfinder/userfiles/files/25\%2C11\%2C13-1.doc

Ragulina M.V. Kulturnyiy landshaft: integralnyiy vzglyad. Ulyanovsk: Zebra, 2015. - 147 s.

Simonov Yu.G. Kulturnyiy landshaft kak ob'ekt geograficheskogo analiza // Kulturnyiy landshaft: voprosyi teorii i metodologii issledovaniy. - Moskva-Smolensk: SGU, 1998. - S. 34-44.

Solntsev N.A. Uchenie o landshafte: Izbrannyie trudyi [Teaching of landscape: Selected works] / N.A. Solntsev; MGU im. M.V. Lomonosova, Geogr. fak. - M.: Izdvo MGU, 2001. - 383 s.: il. 56.

\section{References}


Suleymanov A.A. Formirovanie nauchnogo landshafta selskih rayonov Yakutii v HH v. [The formation of the scientific landscape in rural areas of Yakutia in the twentieth century] // Teoriya i praktika obschestvennogo razvitiya. 2014. \#16. - Elektronnyiy dostup: http://teoria-practica.ru/rus/files/arhiv_zhurnala/2014/16/history/suleymanov.pdf

Vinokurov M.A. Chto takoe turizm? [What is tourism?]
// Izvestiya Irkutskoy gosudarstvennoy ekonomicheskoy akademii. - 2004. -\# 3. - S. 19-24.

Vinokurova L.I., Filippova V.V., Sannikova Ya.M. Selskiy kulturnyiy landshaft Yakutii: opyit mezhdistsiplinarnogo polevogo proekta [The rural cultural landscape of Yakutia: experience of an interdisciplinary field project] // Severo-Vostochnyiy gumanitarnyiy vestnik.2014.- \#2.- S.17-24.

\section{About the authors \\ VIKTORIYA VIKTOROVNA FILIPPOVA}

Senior Researcher

The Institute for Humanities Research and Indigenous Studies of the North, Siberian branch of the Russian Academy of Sciences, Russian Federation

\section{Main research area}

History, historical geography, GIS technology, climate change, demography and settlement of indigenous people, traditional nature use

\section{Address}

Petrovskogo st. 1, Yakutsk,

Russia, 677027

Tel. +79627354796

E-mail: filippovav@mail.ru

\section{SÉBASTIEN GADAL}

Professor

Aix-Marseille Université, CNRS ESPACE UMR 7300

\section{Main research area}

Remote sensing, GIS, spatial analysis, urban studies, territorial development

\section{Address}

ESPACE (UMR 7300) - CNRS

/ Aix-Marseille University, Technopole de l'environnement Arbois Méditerranée, avenue Louis Philibert - BP 80 Bâtiment Laennec, hall $C, 13545$ Aix-en-Provence cedex 04, France

Tel. +33698983040

E-mail: sebastien.gadal@univ-amu.fr

\section{ANTONINA NIKOLAEVNA SAVVINOVA}

\section{Associate Professor \\ M.K. Ammosov North-Eastern federal university, Institute of Natural Sciences, Department of Ecology and Geography \\ Main research area \\ Human geography, GIS, Remote sensing traditional nature use of Indigenous Peoples \\ Address \\ Kulakovskogo st. 48, Yakutsk, Russia, 677000 \\ Tel. +79142368813 \\ E-mail: sava_73@mail.ru}

\section{KAMIČAITYTÉ-VIRBAŠIENĖ}

\section{Professor}

Kaunas University of Technology, Faculty of Civil Engineering and Architecture, Department of Architecture and Urbanism

\section{Main research area}

Landscape visual quality analysis, evaluation and regulation, methods of planned activity or object visual impact assessment, analysis of social preferences evaluating landscape visual quality and use of the analysis results in territory planning, evaluation of the potential of urban structures, research of cityscape identity, expression of sustainable development conception in architecture, landscape architecture, town and territory planning

\section{Address}

Studentu st. 48, LT-51367 Kaunas, Lithuania

Tel. +37061477082

E-mail: jurate.kamicaityte@ktu.lt

\section{YURI GEORGIEVICH DANILOV}

\section{Professor}

M.K. Ammosov NorthEastern federal university, Institute of Natural Sciences, Department of Ecology and Geography

\section{Main research area}

Physical geography, landscape science, climatology

\section{Address}

Kulakovskogo st. 48, Yakutsk, Russia, 677000 Tel. +79142225104

E-mail: dan57sakha@mail.ru 